\title{
Is a periglacial biota responsible for enhanced dielectric response in basal ice from the Greenland Ice Core Project ice core?
}

\author{
Jean-Louis Tison, ${ }^{1}$ Roland Souchez, ${ }^{1}$ Eric W. Wolff, ${ }^{2}$ John C. Moore, ${ }^{3}$ \\ Michel R. Legrand, ${ }^{4}$ and Martine de Angelis ${ }^{4}$
}

\begin{abstract}
A detailed dielectric profiling (DEP) conductivity profile $\left(\sigma_{\infty}\right)$ measured in the $6 \mathrm{~m}$ of the basal silty ice sequence from the Greenland Ice Core Project (GRIP) ice core (Summit, Central Greenland) is presented and compared to previous multiparametric studies. DEP conductivities span the whole glacial-interglacial range observed higher up in the GRIP core $\left(9-25 \mu \mathrm{S} \mathrm{m}^{-1}\right)$. Values in the bottom meter of the sequence reach the level of some of the highest peaks from Holocene volcanic layers in the core $\left(33 \mu \mathrm{S} \mathrm{m}^{-1}\right)$. On a steady increase of the $\sigma_{\infty}$ values down the sequence are superimposed large fluctuations "inphase" with other variables measured in the core such as $\delta^{18} \mathrm{O}$, debris content, or gas compositions in $\mathrm{CO}_{2}$ and $\mathrm{CH}_{4}$. Analysis of the type and strength of intercorrelations shows that the controlling variable for the DEP signal must be closely related to the gas content and composition of the ice. Plausible candidates for this causality link are investigated. Enhancing of the $\sigma$ conductivity by $\mathrm{CO}_{2}$ and $\mathrm{CH}_{4}$ encaged in the ice lattice as gas hydrates is ruled out since these are nonpolar clathrates of structure I, known as having negligible impact on the orientational stability of the water molecules under ac currents. $\mathrm{NH}_{4}{ }^{+}$is proposed as the best candidate since it has been shown to enhance DEP conductivities by introducing Bjerrum defects in the ice lattice and since it could have been initially present partly as gaseous $\mathrm{NH}_{3}$ in the ice. This proposition is supported by the $\mathrm{NH}_{4}{ }^{+}$ profile in the basal ice sequence. Using calibration curves from higher up in the core, it is shown that $\sigma$ is in fact fully explained by intracrystalline conductivity of pure ice solely disrupted by ammonium impurities in the ice lattice. The origin of the $\mathrm{NH}_{4}{ }^{+}$signal is discussed in the light of organic acid profiles (formate, acetate, and oxalate). It appears that the most likely source is local degradation of biological residues, which supports the hypothesis that part of the basal ice was formed locally, in the absence of the present-day ice sheet.
\end{abstract}

\section{Introduction}

In the framework of the Greenland Ice Core Project (GRIP), deep drilling was conducted from 1990 to 1992 at the very top of the Greenland Ice Sheet (GIS) on the main ice divide (Summit, 72\$34'N, 37\$37'W). Drilling stopped near the bedrock at a depth of $3028.65 \mathrm{~m}$, after penetration of $6.13 \mathrm{~m}$ of basal debris-rich ice (often referred to as "silty ice," given its debris particulate size, content, and distribution). Previous work has already provided detailed descriptions and interpretation schemes of the basal ice sequence

\footnotetext{
${ }^{1}$ Département des Sciences de la Terre et de l'Environnement, Université Libre de Bruxelles, Brussels.

${ }^{2}$ British Antarctic Survey, National Environment Research Council, Cambridge, England, United Kingdom.

${ }^{3}$ Arctic Center, University of Lapland, Rovianemi, Finland.

${ }^{4}$ Laboratoire de Glaciologie et Géophysique de l'Environnement, Centre National de la Recherche Scientifique, Grenoble, France.
}

Copyright 1998 by the American Geophysical Union.

Paper number 98JD01107.

0148-0227/98/98JD-01107\$09.00 at GRIP suggesting dynamical mixing between ice of local origin and ice invading the site from upslope during the original buildup of the ice sheet as the most likely mechanism [Souchez, 1997; Souchez et al., 1995a, b, 1994; Tison et al., 1994; Weis et al., 1997]. Figures 1 and 2 summarize some of the main results from these multiparametric approaches, combining data sets on ice texture and fabrics, debris content, stable isotopes of oxygen and hydrogen, total gas content, and gas composition.

The basal ice sequence is formed of three major textural units (Figure 1). Clear bubble-free ice with very large crystals (mean value of $26 \mathrm{~mm}$ in diameter), showing polygonal straight boundaries, forms the upper unit of the core, just above the contact with the first layer of silty ice (3022.25-3022.52 m). Debris is not absent in this unit but is limited to a few coarse sandy grains. From 3022.52 to $3023.81 \mathrm{~m}$, a second unit is characterized by an alternation of debris-free ice and light brown debris-loaded ice bands (up to $0.10 \%$ debris weight; indicated by the light gray layers in Figures 1, 3, and 4). The upper debris-free ice layers are similar to those in unit 1 , whilst the lower ones are smaller grained (maximum of 6-8 $\mathrm{mm}$ in diameter) and contain scattered intracrystalline bubbles of a size of the order of a millimeter. In the debris-loaded bands, crystal 

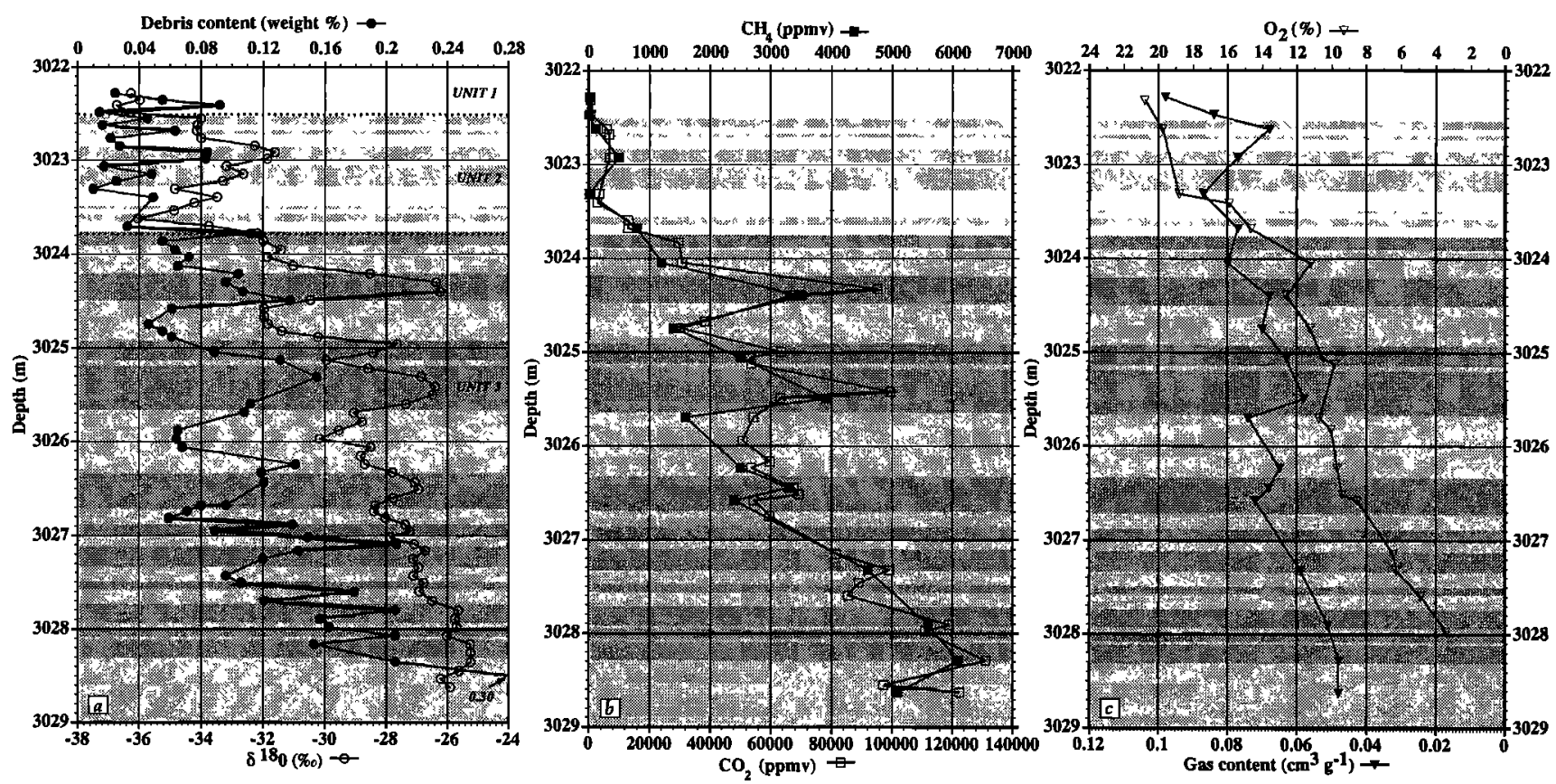

Figure 1. Multiparametric profiles are given from previous studies on the basal silty ice sequence at Greenland Ice Core Project (GRIP) [after Souchez et al., 1995a, b]. The gray scale in the background is a qualitative estimate of the debris load, through visual inspection of the cores in transmitted light.

sizes are between 4 and $6 \mathrm{~mm}$ in diameter, and debris are typically silty and homogeneously distributed in the band. The third and last unit (unit 3) forms the bottom part of the core (3023.81-3028.65 m) and consists of continuously brownish debris-loaded ice with small equigranular crystals (a few millimeters in diameter). A rough banding is still present (light and dark gray banding in Figures 1, 3, and 4) because of the variable dirt content that is globally increasing from 0.05 to $0.3 \%$ in weight toward the bottom of the sequence. These dirt contents are similar to those found in the basal ice of the Dye- 3 ice core [Tison et al., 1994].

The $\delta^{18} \mathrm{O}$ values in the basal ice (open circles in Figure 1a) show an extremely large range from $-37 \%$ in unit 1 to $-25 \%$ at the base of unit 3 , with considerable fluctuations along the profile, and a major $\delta^{18} \mathrm{O}$ gradient between 3023.65 and $3024.40 \mathrm{~m}$ depth. Souchez et al. [1994] demonstrated that the extremely high values observed in the bottom layers can only be understood if ice that formed in the absence of the ice sheet largely contributed to its formation. Another striking feature of the data sets presented in Figure 1 is the strong similarity between all the profiles (dirt content, $\mathrm{CH}_{4}, \mathrm{CO}_{2}$, reversed $\mathrm{O}_{2}$, and reversed total gas content) and the $\delta^{18} \mathrm{O}$ profile. This feature was used by Souchez et al. [1995a, b] to propose that a flowinduced mixing process has occurred within the basal ice between two end-members: the basal ice from the growing ice- sheet (probably during the growing stage of initial buildup) and a "local" end-member formed at the ground surface in a marshy anaerobic environment. This assertion is supported by Figure 2, in which mixing between the two end-members $(0-100 \%$ of the local end-member for $\delta^{18} \mathrm{O}$ and $\mathrm{CO}_{2}$, which are enriched downward, and 0-100\% of the "base of growing ice sheet" end-member for $\mathrm{O}_{2}$, which is depleted downward) has been modeled using best estimates of the two end-member characteristics. Because the gas concentrations are measured in ppmv (parts per million of air volume) and because there is a steady decrease of the total gas content down the profile, model outputs do not lie on the diagonal (dashed line in Figure 2) of the diagram. Sample points match the predictions of the mixing model well. Departures from the model result from postmixing diffusion around the major peaks [Souchez et al., 1995a]. The fact that the best match between the mixing model and the observations is obtained by using local

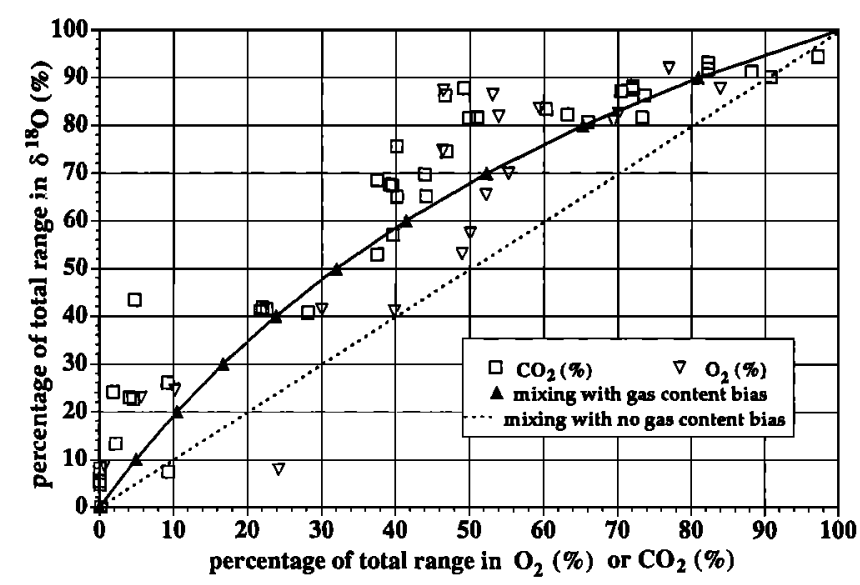

Figure 2. Comparison of $\mathrm{CO}_{2}$ and $\mathrm{O}_{2}$ sample values from the basal silty ice sequence at GRIP with the mixing model [after Souchez et al., 1995a, b]. Percentages of total range in $\mathrm{O}_{2}$ and $\mathrm{CO}_{2}$ are calculated using ppmv units (parts per million of air volume in the ice). Therefore, because of the steady decrease of the total gas content in the ice ( $\mathrm{mL}$ air/kg of ice), the mixing curve is not a straight line (gas content bias). 
$\sigma_{\infty}\left(\mu \mathrm{S} \mathrm{m}^{-1}\right) \quad(2 \mathrm{~cm}$ resolution $\cdots \cdots$, , averaged $(\star))$
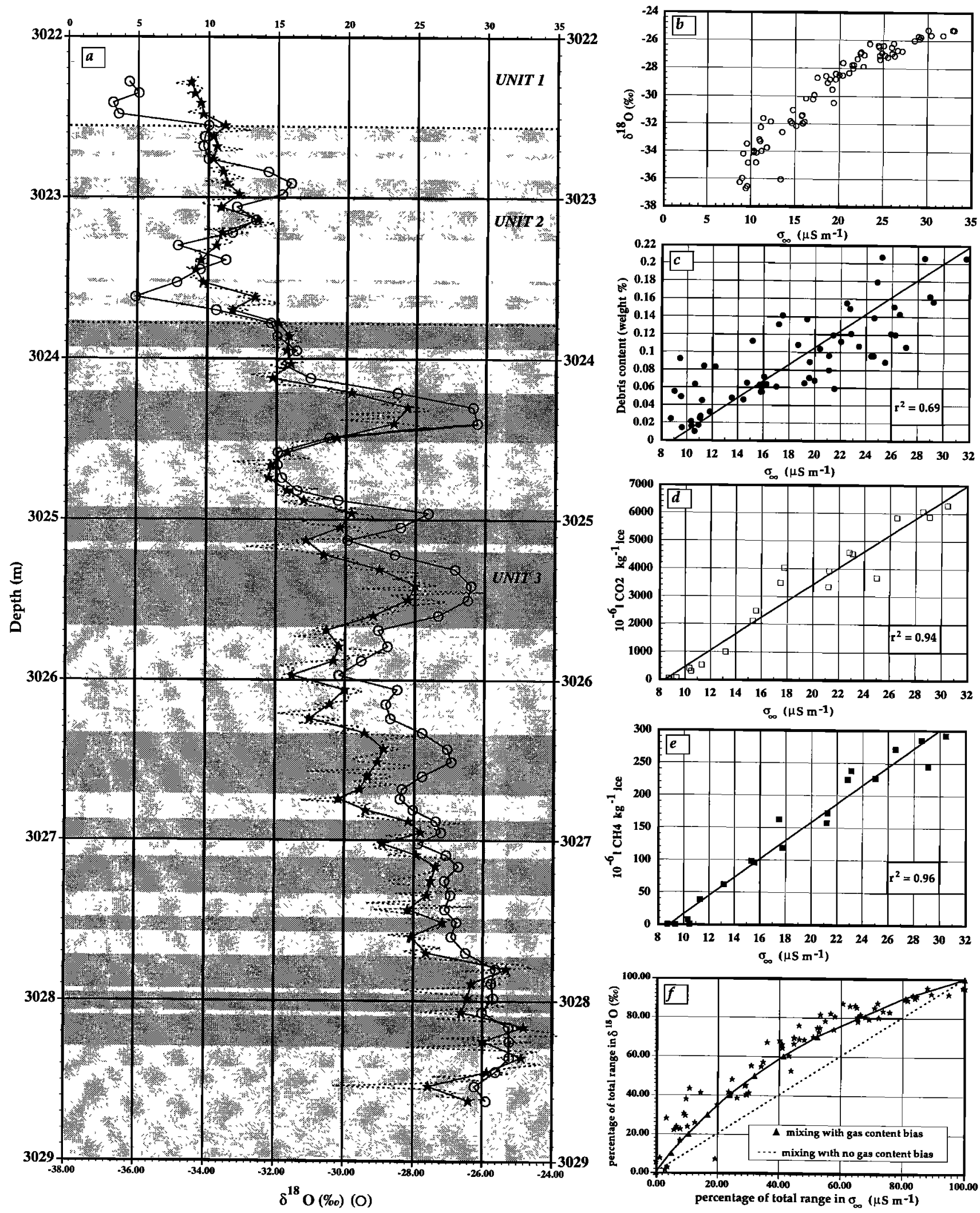

Figure 3. (a) Compared $\sigma_{\infty}$ (dielectric profiling (DEP)) and $\delta^{18} \mathrm{O}$ profiles are shown with depth in the basal sequence of the GRIP core. Correlations are shown with (b) $\delta^{18} \mathrm{O}$, (c) debris content in weight percent, (d) $\mathrm{CO}_{2}$ and (e) $\mathrm{CH}_{4}$ concentrations per kilogram of ice. (f) A comparison is given of the sample's $\sigma_{\infty}$ values to the mixing model shown in Figure 2 (see text for details). Dashed curve in Figure 3a shows the full $\sigma_{\infty}$ profile at the $2 \mathrm{~cm}$ resolution level. The resolution of the textural profile (about 8 $\mathrm{cm}$ ) has been chosen as a common base to average both the DEP (stars) and the $\delta^{18} \mathrm{O}$ values (open circles) in Figures $3 a, 3 b$, and $3 f$. In Figures $3 c-3 e$ the $\sigma_{\infty}$ values have been averaged down to the resolution of the other variables. 


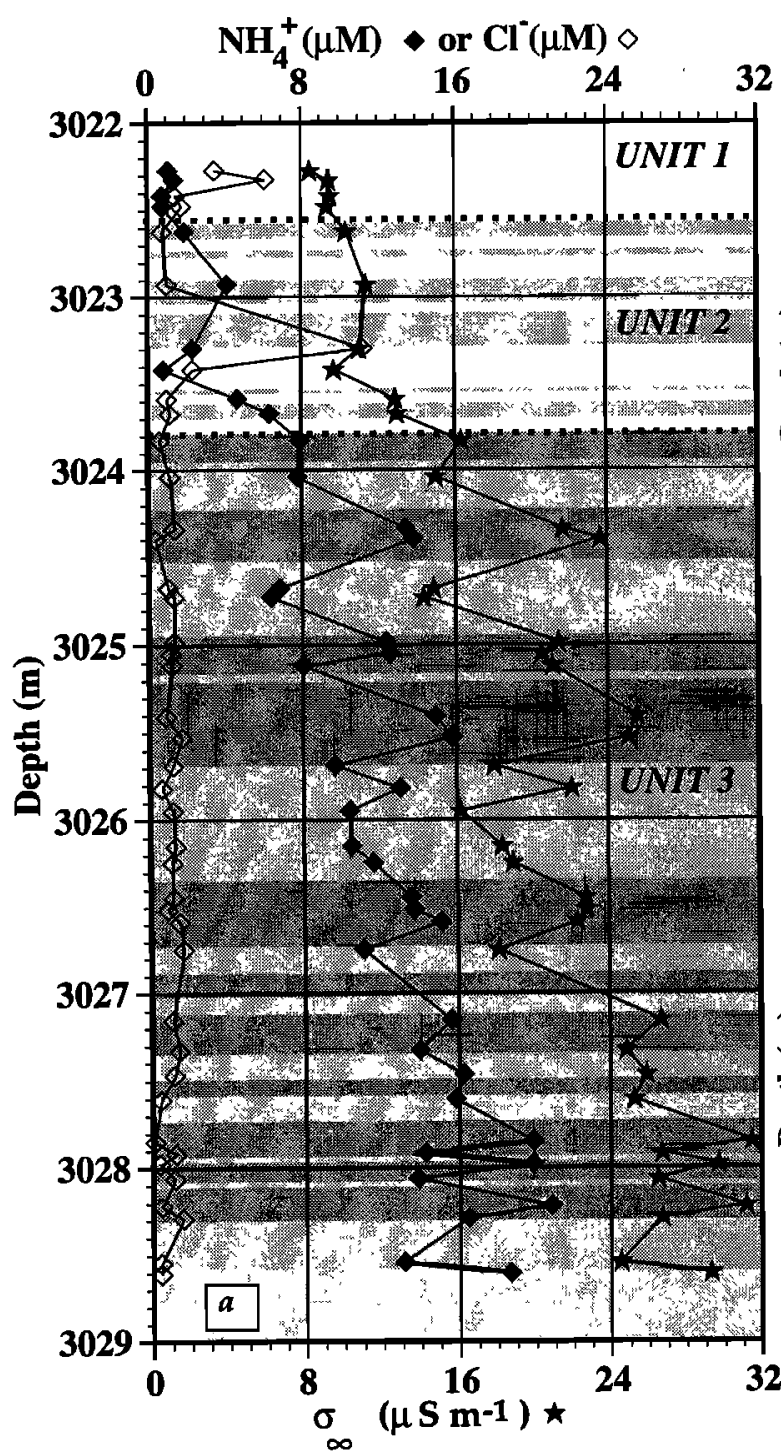

Calculated $\sigma_{\infty}\left(\mu \mathrm{S} \mathrm{m}^{-1}\right) \mathrm{O}$

Relative error on $\sigma_{\infty}(\%)$

$\begin{array}{llllll}32 & 0 & 8 & 16 & 24 & 32\end{array}$

$-60-40-200204060$
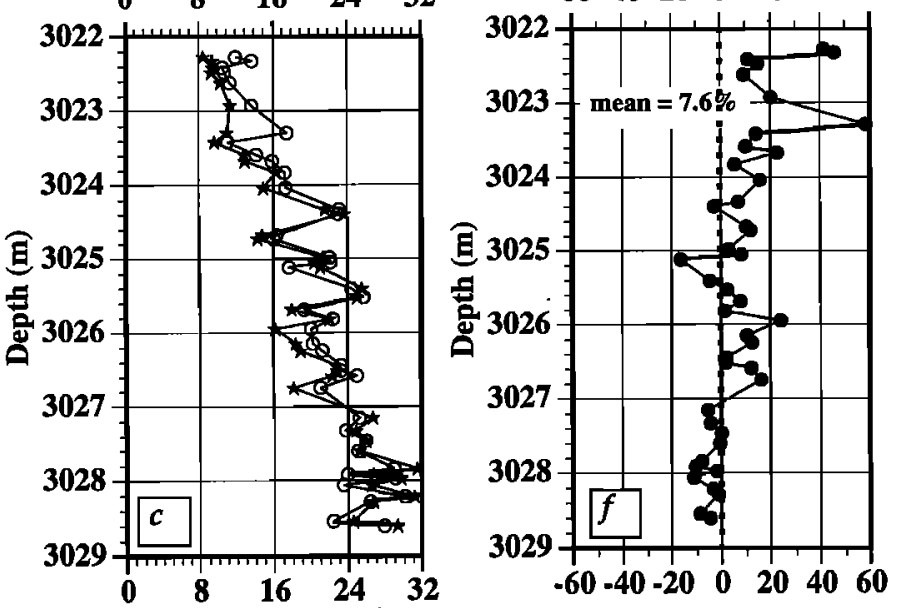

Observed $\sigma \quad\left(\mu \mathrm{s} \mathrm{m}^{-1}\right) \star$

Calculated $\sigma^{\infty}\left(\mu \mathrm{S} \mathrm{m}^{-1}\right) 0$

Relative error on $\sigma_{\infty}(\%)$

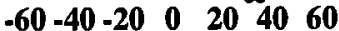
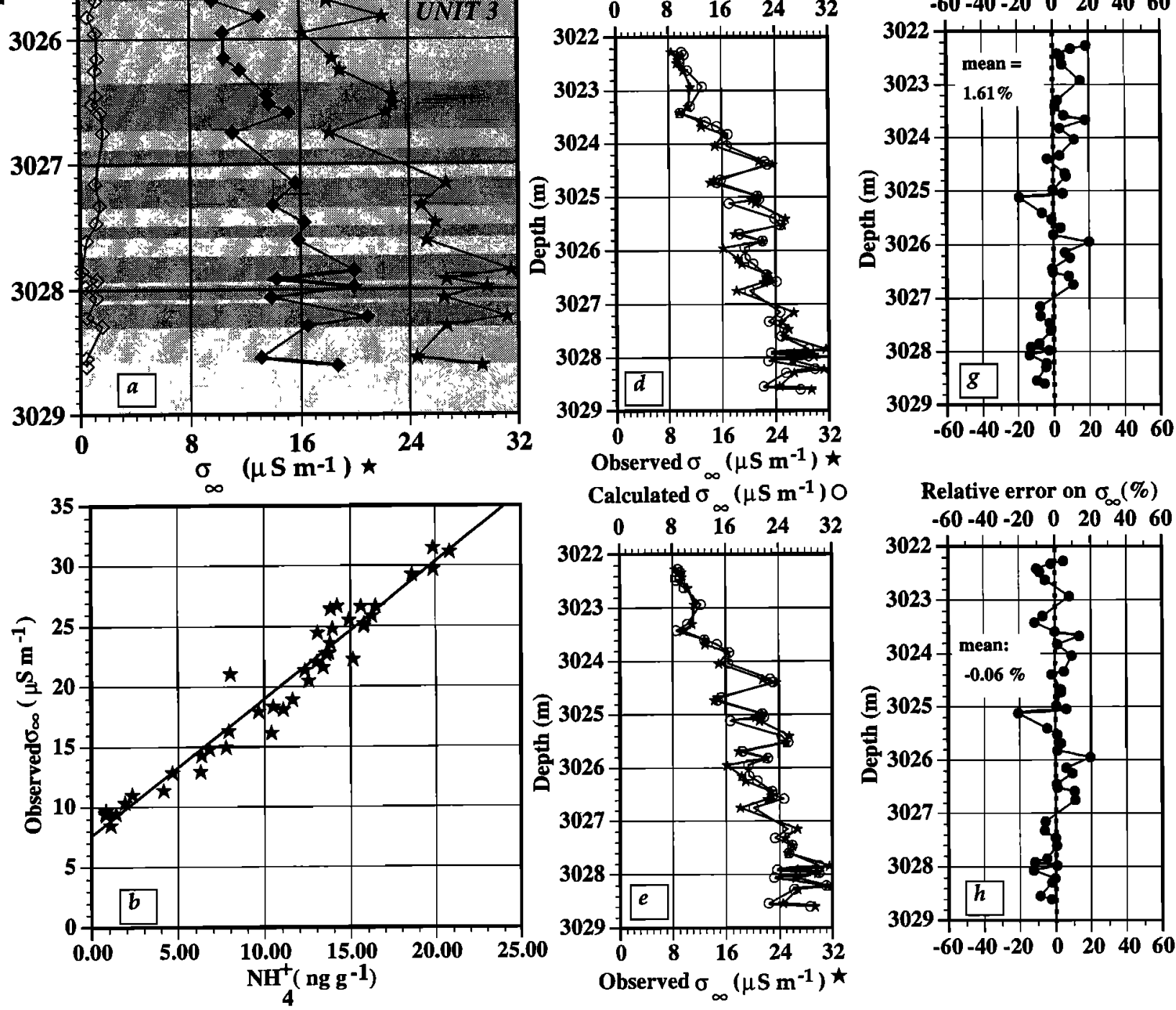

Relative error on $\sigma_{\infty}(\%)$

$-60-40-20 \quad 0 \quad 204060$

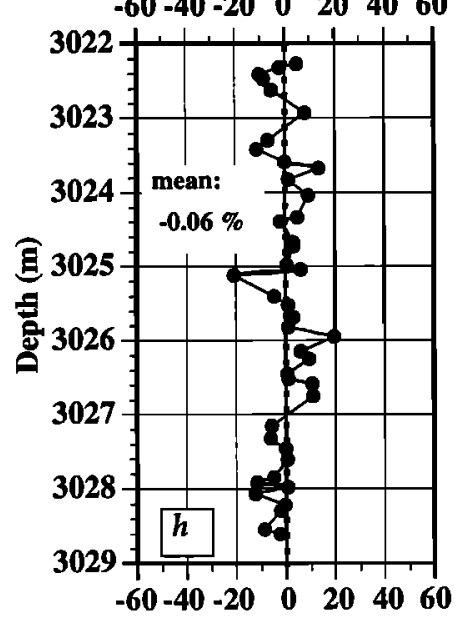

Figure 4. (a) $\mathrm{NH}_{4}^{+}$and $\mathrm{Cl}^{-}$profiles in the basal silty ice sequence at GRIP are shown. (b) A diagram is given showing the $\sigma_{\infty} / \mathrm{NH}_{4}^{+}$relationship for the samples. (c)-(e) Comparisons are shown of the observed profile to calculated values using different calibrations. (f)-(h) Relative errors are shown ( $\sigma_{\text {cal }}$ $\sigma_{\text {obs }} / \sigma_{\text {obs. }}$ ) for the same calibrations. Calibrations are from equation (2) for Figures $4 \mathrm{c}$ and $4 \mathrm{f}$, from equation (3) for Figures $4 \mathrm{~d}$ and $4 \mathrm{~g}$, and from a linear regression through the data for Figures $4 \mathrm{e}$ and $4 \mathrm{~h}$. In all diagrams, to reduce possible errors due to the mismatch between the two data sets, the resolution of the DEP record $(2 \mathrm{~cm})$ has been increased to the $0.5 \mathrm{~cm}$ level using linear interpolation, and the values have been averaged in the respective depth range of each chemical sample. 
end-member's values in the model that are very close to those of the bottom basal ice samples suggests that the drilling stopped close to the actual bedrock.

This work discusses new data on the dielectric and selected chemical profiles of the basal ice sequence in the GRIP core, and it shows how the enhanced dielectric response of the basal ice can be related to environmental conditions during the formation of the local end-member. A periglacial biota, with significant plant cover and efficient biological activity, appears to satisfactorily explain the basal ice characteristics observed.

\section{Methods}

DEP measurements were performed by the British Antarctic Survey (BAS), using a setup similar to the one described by Moore and Paren [1987] and Moore et al. [1992b]. The whole core was placed onto a lower curved continuous aluminum electrode. A set of curved segmented aluminum electrodes, each $2 \mathrm{~cm}$ across, was closed over the core. Using an applied voltage of $1 \mathrm{~V}$, the dielectric response of each $2 \mathrm{~cm}$ section was determined using a computer-controlled bridge sweeping the AF-LF frequency range. The electrodes were all coated with a nonconducting plastic film so that there was no direct contact with the ice. For each $2 \mathrm{~cm}$ section, one top electrode was "active" while the two on either side acted as guard electrodes. The computer made each segment active in turn so that a profile of dielectric properties along the core was obtained. Raw DEP data consist of conductance and capacitance measurements at a range of frequencies that span the main dielectric dispersion of ice [Hobbs, 1974]. From a range of properties that can be derived (see, for example, Moore et al. [1989]), $\sigma_{\infty}$, the high-frequency limit of the conductivity, has proved to be the most useful, and it will be reported throughout this paper. Measurements were made at trench temperatures between $-25^{\circ}$ and $-10^{\circ} \mathrm{C}$, and they have been normalized at $-15^{\circ} \mathrm{C}$ using the appropriate activation energies for the corrections of raw data according to Moore et al. [1992b, 1994b]. Precision of the measurements is often controlled by the T-correction and is of the order of $5-10 \%$.

Forty-two samples of about $30 \mathrm{~mL}$ of ice, with a mean depth resolution of $2.5 \mathrm{~cm}$, were collected at the Universite Libre de Bruxelles (ULB) using a diamond-wire saw adapted to cut fragile heterogeneous frozen material [Tison, 1994]. Sample locations were chosen at the same levels where the gas analyses were performed. Only on a few occasions were the gas samples a bit longer (by $1-2 \mathrm{~cm}$ ), to avoid a possible alteration of the results due to fissures in the ice. Samples were transferred in the solid state to the Laboratoire de Glaciologie et Géophysique de l'Environnement (LGGE), where careful cleaning was performed within the clean room facilities. Before analysis, samples were filtered through polycarbonate filters $0.4 \mu \mathrm{m}$ in diameter. Among others, ammonium $\left(\mathrm{NH}_{4}{ }^{+}\right)$, chloride $\left(\mathrm{Cl}^{-}\right)$, formate $\left(\mathrm{HCOO}^{-}\right)$, acetate $\left(\mathrm{CH}_{3} \mathrm{COO}^{-}\right)$, and oxalate $\left(\mathrm{C}_{2} \mathrm{O}_{4}^{-}\right.$ ) ions were measured by ion chromatography using a Dionex 4500 and the procedures described by Legrand et al. [1993]. Typical precision of the measurements (taking into account blank values) is $\pm 6 \%$ for $\mathrm{NH}_{4}{ }^{+}, \pm 1.5 \%$ for $\mathrm{Cl}^{-}$, $\pm 1.5 \%$ for $\mathrm{HCOO}^{-}, \pm 9.5 \%$ for $\mathrm{CH}_{3} \mathrm{COO}^{-}$, and $\pm 3 \%$ for $\mathrm{C}_{2} \mathrm{O}_{4}{ }^{--}$.

\section{Electrical Stratigraphy in Polar Ice}

Two main techniques were developed in the last decade to explore the electrical stratigraphy in ice, and they were recently applied, for the first time simultaneously, on the GRIP ice core in Greenland [Moore et al., 1994b; Wolff et al., 1995, 1997a, b]. Wolff et al. [1997a] present a summary of both techniques and of their relationship to the ice chemistry. These will therefore only be briefly addressed below. The electrical conductivity method (ECM) [Hammer, 1980, 1983] is a direct current $(\mathrm{dc})$ method where a high voltage $(1250 \mathrm{~V})$ is applied across a pair of brass electrodes running along the ice at a speed of a few $\mathrm{cm} \mathrm{s}^{-1}$. The surface of the core has to be planed and refreshed with a microtome knife, which makes the technique partially destructive. It measures the intensity of the current $(\mu \mathrm{A})$ flowing between the electrodes, and the resolution is of the order of a few millimeters. The DEP [Moore et al., 1989; Moore and Paren, 1987], as described in section 2 , measures low-voltage $(1 \mathrm{~V})$ alternating currents in the $20 \mathrm{~Hz}-300 \mathrm{kHz}$ frequency range. It is a nondestructive method and measures capacitance and conductances as raw data. Derived variables are $\sigma_{\infty}$ (highfrequency limit conductivity) and $\mathrm{f}_{\mathrm{r}}$ (relaxation frequency).

Extensive databases are now available on the chemistry of polar ice cores to allow for a detailed calibration of dc ECM and DEP $\sigma_{\infty}$ conductivities against impurity concentrations in the ice [e.g., Wolff et al., 1995, 1997a, b]. It has been shown that ECM primarily responds to the $\left[\mathrm{H}^{+}\right]$ concentration in the ice, with some scatter in the calibration curves mainly inherent to incertitudes from both the $\left[\mathrm{H}^{+}\right]$and the ECM measuring procedures. Some dispersion might also result from the identity of the anions associated with the $\left[\mathrm{H}^{+}\right]$, affecting, in some cases, the strength of the response. Similarly, the DEP $\sigma_{\infty}$ conductivity appears to be dependent solely on three chemical components, namely, $\mathrm{H}^{+}, \mathrm{NH}_{4}{ }^{+}$, and $\mathrm{Cl}^{-}$. The current preferred composite relationship for the DEP conductivity of solid ice at $-15^{\circ} \mathrm{C}$ is [Wolff et al., 1995]

$$
\sigma_{\infty}=4\left[\mathrm{H}^{+}\right]+1\left[\mathrm{NH}_{4}^{+}\right]+0.55\left[\mathrm{Cl}^{-}\right]+9
$$

Although it is mainly based on data from the GRIP ice core and obviously requires validation from other locations, this relationship seems to satisfactorily explain all of the thousands of peaks in the core, as well as the major trends.

Authors generally agree that intracrystalline conductivity as described by the Jaccard theory plays an important role in the conduction mechanisms driving the ECM and DEP responses in the ice. In that context, the dc conductivity would be controlled by the minority charge carriers (ionic $\mathrm{H}_{3} \mathrm{O}^{+}$defects), while at higher frequencies the majority carriers (Bjerrum $L$ and $D$ defects) would be more important. The natural content of the Bjerrum defects of pure single ice crystals is responsible for the conductivity that is expected to amount to $9 \mu \mathrm{S} \mathrm{m}^{-1}$ at $-15^{\circ} \mathrm{C}$ [Camplin et al., 1978]. This explains the independent term in (1). Impurities like $\mathrm{NH}_{4}{ }^{+}$(or $\mathrm{NH}_{3}$ ) and $\mathrm{Cl}^{-}$(or $\mathrm{HCl}$ ) are likely to enter the ice lattice since the covalent radius for $\mathrm{N}$ and $\mathrm{Cl}$ is similar to that for oxygen atoms. These components will then increase the DEP conductivity by increasing the number of $\mathrm{L}$ or $\mathrm{D}$ defects in the lattice. As discussed by 
Wolff et al. [1997a], there is still some debate as to whether $\left[\mathrm{H}^{+}\right]$conductivity is exclusively driven by intracrystalline processes (minority charge carriers) or is the result of grain boundary conduction. The presence of high concentrations of sulfur at triple junctions in some samples of polar ice [Mulvaney et al., 1988] and the onset of an ECM current in marine ice with brines at grain boundaries suggest that dc conductivity could occur through the intercrystalline subliquid layer down to very low temperatures. It is, however, difficult to explain with this mechanism, at least in simple terms, the observations of persisting ECM conductivities in single large crystals from deep ice or the curvature observed in ECM calibration graphs [Hammer, 1980; Moore et al., 1992b].

\section{High-Resolution Dielectric Profiling in the GRIP Basal Ice}

Figure $3 a$ shows the $\sigma_{\infty}$ profile with depth in the basal ice sequence from the GRIP core. The $\sigma_{\infty}$ values increase steadily from top to bottom, spanning the whole range of values observed higher up in the core. Starting with very low values close to those of pure single ice crystals $(9 \mu \mathrm{S}$ $\left.\mathrm{m}^{-1}\right)$ and typical of the isotopically cold periods $(9-12 \mu \mathrm{S}$ $\left.\mathrm{m}^{-1}\right)$, it reaches, in the bottom meter, values higher than those observed during the isotopically warm periods (15-25 $\mu \mathrm{S} \mathrm{m} \mathrm{m}^{-1}$ ), with a maximum of $33 \mu \mathrm{S} \mathrm{m} \mathrm{m}^{-1}$. Moore et al. [1994b] and Wolff et al. [1997a] explain the contrast between cold and warm periods in the GRIP core (also valid in other Greenland ice cores) by the fact that in colder periods any atmospheric acidity present is neutralized by $\mathrm{CaCO}_{3}$ dusts, more abundant in the ice during these episodes. There is thus a general rule of warmer acidic periods with higher ECM (dc) signals $\left(0.5<\left[\mathrm{H}^{+}\right]<2 \mu \mathrm{M}\right.$, excluding volcanic events) and colder alkaline periods with negligible ECM signals $\left(\left[\mathrm{H}^{+}\right]<0.1 \mu \mathrm{M}\right)$. According to the same authors, this contrast is also the main control on the gross changes in the DEP signal, although other factors are also important there. For example, as already mentioned in section 3, the localized DEP peaks during the cold Younger Dryas period are mainly attributed to $\mathrm{NH}_{4}^{+}$ concentrations peaks.

Unfortunately, no ECM profile is presently available for the basal ice from GRIP. However, ECM measurements on the basal ice from the Dye- 3 ice core (located about 800 $\mathrm{km}$ south of Summit and $200 \mathrm{~km}$ on a northward flow line from South Dome), showing similar dirt content and distribution, gave values at the level of the detection limits (H. Clausen, personal communication, 1996). If one considers this as also valid for the basal ice from the GRIP core (as will be demonstrated in section 5), we then have a peculiar behavior where low dc and high ac conductivity coexist, most of the DEP signal therefore resulting from nonacidic intracrystalline impurities.

Figure $3 \mathrm{a}$ also compares the $\sigma_{\infty}$ to the $\delta^{18} \mathrm{O}$ profile in the basal ice sequence from the GRIP core. It is clear that as already described for the variables previously studied, there is a close agreement between the two profiles. However, Figure $3 \mathrm{~b}$ shows that the relationship is not linear with $\delta^{18} \mathrm{O}$, suggesting that it is not a causality link but simply the fingerprint of the mixing process on the different variables [Souchez et al., 1995a, b]. It is worth noting here that very little is known concerning the effect of solid impurities on the dielectric properties of the ice. For example, it has been shown that fine particles (fine silts and clays) may act as efficient "cation carriers" in the adsorbed state on the particles' broken edges [Caroll, 1959; Hellferich, 1962]. Ion exchanges between the particles and the subliquid layer in a polycrystalline aggregate could release soluble impurities eventually included into the ice lattice. Although a linear relationship exists between the debris content (in weight percent) and $\sigma_{\infty}$ (Figure $3 c$ ), the correlation is, however, too weak $\left(r^{2}=0.69\right)$ to argue in favor of a causality link.

On the contrary (Figures $3 \mathrm{~d}$ and $3 \mathrm{e}$ ), stronger correlation coefficients exist with the $\mathrm{CO}_{2}$ and $\mathrm{CH}_{4}$ concentrations expressed per kilogram of ice $\left(\mathrm{r}^{2}\right.$ of 0.94 and 0.96 , respectively). This is especially clear in Figure $3 f$, where the $\sigma_{\infty}$ samples' behavior follows the mixing curve with gas content bias, already presented in Figure 2. This last observation is of crucial importance since it implies that any explicative variable for the DEP signal will have to fulfill the following conditions: (1) be able to introduce defects in the lattice that enhance the DEP signal and (2) be associated with the gaseous phase in the ice.

\section{In Search of a Plausible Candidate}

In an early study of the electrical behavior of finely divided ice, Paren and Glen [1978] extensively discussed the possible effect of $\mathrm{CO}_{2}$ adsorption at the surface of ice crystals on the enhancement of the dielectric properties of the ice. Following Alder et al. [1969], these authors suggested that $\mathrm{CO}_{2}$ initially adsorbed as a monolayer on snow and firn crystals (with high specific surface area of the ice-air interface) would subsequently be incorporated into the ice lattice, generating $\mathrm{H}_{3} \mathrm{O}^{+}$ions and Bjerrum $\mathrm{L}$ defects. However, as mentioned by Paren and Glen, no model was available at the time on the bonding of the molecules to the lattice or on the possible defect reactions that may occur. In any case, one should remember that the GRIP DEP was measured in the field, shortly after the retrieval of the basal ice section of the core, from depths beyond $3000 \mathrm{~m}$. In these conditions it is quite plausible, given also the low dissociation pressures of $\mathrm{CO}_{2}\left(12.710^{5} \mathrm{~N} \mathrm{~m}^{-2}\right.$ at $\left.0^{\circ} \mathrm{C}\right)$ and $\mathrm{CH}_{4}\left(26.310^{5} \mathrm{~N} \mathrm{~m}^{-2}\right.$ at $\left.0^{\circ} \mathrm{C}\right)$, that most of the gases were still present in the clathrate form (air hydrate, fully "caged" into the ice lattice) at the time of the measurements.

Gough and Davidson [1973] and Davidson [1973] provided a comprehensive study of clathrate hydrates. Structurally, depending on the number of water molecules forming the unit cell caging the guest molecule, clathrate hydrates have been classified as "structure I" (46 water molecules per unit cell) or "structure II" (136 water molecules per unit cell). Both $\mathrm{CO}_{2}$ and $\mathrm{CH}_{4}$ clathrates are nonpolar hydrates of structure I. Probably because of their more volatile type causing experimental problems in measuring their dielectric behavior, $\mathrm{CO}_{2}$ and $\mathrm{CH}_{4}$ clathrates have not been extensively studied. However, the main conclusion of Gough and Davidson was that in the absence of perturbation by relatively large and polar guest molecules, the water molecules in clathrate hydrates are about as orientationally stable as those in pure Ih itself. This 
probably rules out $\mathrm{CO}_{2}$ or $\mathrm{CH}_{4}$ as plausible candidates for driving the $\sigma_{\infty}$ response of the basal ice from GRIP.

Since previous work on the GRIP core has indicated the critical role of ammonium and chloride in driving the $\sigma_{\infty}$ term linked with intracrystalline defects and since the first could have initially existed in the $\mathrm{NH}_{3}$ gaseous form, the next logical step was to measure $\mathrm{NH}_{4}^{+}$and $\mathrm{Cl}^{-}$profiles in the basal ice sequence. These are shown in Figure 4a and are compared with the $\sigma_{\infty}$ profile. The chloride profile shows a contrasting behavior with very low values (about $1 \mu \mathrm{M} \mathrm{Cl}^{-}$) throughout all the silty ice and shows higher values in the clear ice layers of units 1 and 2 (7-11 $\mu \mathrm{M}$ $\left.\mathrm{Cl}^{-}\right)$. This fits the idea of contrasted origins for the two end-members in the mixing model [Souchez et al., 1995a, b]. The clear ice of the base of the growing ice sheet's endmember, thought to have formed closer to the coast in the eastern mountainous range, carries lower $\delta$ values (colder ice) and higher $\mathrm{Cl}^{-}$values relative to the silty ice of local origin, formed "in- situ," far away from sea spray sources, and in the absence of the present-day ice sheet (warmer ice).

On the contrary, the $\mathrm{NH}_{4}{ }^{+}$profile faithfully mimics the $\sigma_{\infty}$ profile, and the correlation between the two variables is strong (Figure 4b), suggesting a causality link. It is therefore tempting to apply (1) to the basal ice of GRIP to test its validity. Since no ECM measurement is available, we will consider as a first approximation that as in the Dye-3 basal ice, the $\left[\mathrm{H}^{+}\right]$is negligible. It should be noted in this regard that since the ionic balance ([H-ACY]) is negative for all the samples measured (down to $-50 \mu \mathrm{eql}^{-1}$ ), this assertion is probably valid. Equation (1) is therefore reduced to

$$
\sigma_{\infty}\left(\mu \mathrm{S} \mathrm{m}^{-1}\right)=9+\left[\mathrm{NH}_{4}^{+}\right]+0.55\left[\mathrm{Cl}^{-}\right]
$$

and calculated $\sigma_{\infty}$ are plotted in Figure $4 \mathrm{c}$, where they are compared with the observed values. The relative error on $\sigma_{\infty}$ (expressed as $\left(\sigma_{\text {calc. }}-\sigma_{\text {obs. }}\right) / \sigma_{\text {obs. }}$ in percent) was also computed and is shown in Figure 4f. Major departures from the observed values clearly occur in the clear ice where the chloride content is higher (up to $60 \%$ relative error). Therefore (2) was further reduced to pure ice and $\mathrm{NH}_{4}$ conductivity dependency only :

$$
\sigma_{\infty}\left(\mu \mathrm{S} \mathrm{m}^{-1}\right)=9+\left[\mathrm{NH}_{4}^{+}\right]
$$

and the results were plotted in Figures $4 \mathrm{~d}$ and $4 \mathrm{~g}$. The agreement is now quite good, with a mean relative error of $1.61 \%$ and maximum departures from the observed values of about $20 \%$. This is exactly the range of precision reckoned by Moore et al. [1994b] for the ammonium calibration of $\sigma_{\infty}$, higher up in the GRIP core, given the relatively coarse chemical sampling procedure. For comparison, Figures $4 \mathrm{e}$ and $4 \mathrm{~h}$ plot the calculated $\sigma_{\infty}$ and relative errors using a best fit linear regression across the data. The result is not significantly different, apart from a slightly better mean value on relative errors $(-0.06$ instead of $1.61 \%)$. The proportionality factor between $\sigma_{\infty}$ and $\left[\mathrm{NH}_{4}^{+}\right]$ in the best fit linear regression is also a bit higher than 1 (1.12). Moore et al. [1994a] gave an estimate of this proportionality factor from theoretical considerations on the relationship between $\sigma_{\infty}$ and the concentrations, charges, and the mobility of the Bjerrum defects. They suggest that one $\mathrm{D}$ defect should produce a maximum value of 0.66 for the proportionality constant, and they further deduce that two-dimensional (2-D) defects are needed (with $>75 \%$ efficiency) to explain the value of 1 observed for the DEP peaks of the Younger Dryas. This is certainly also true for the results from the basal ice described here and therefore suggests that part of the ammonium initially present in the gaseous form $\left(\mathrm{NH}_{3}\right)$, as shown in this section, was transformed in $\mathrm{NH}_{4}{ }^{+}$prior to incorporation into the ice lattice, to sustain a sufficient production of 2-D defects. This is quite plausible, even in the presence of very limited amounts of liquid water, given the very high solubility of $\mathrm{NH}_{3}$. Two main conclusions can be drawn from the developments above:

1. The assumption of negligible acidity in the basal ice layer appears to be correct.

2. For the three points (located at $3022.275,3022.328$, and $3023.298 \mathrm{~m}$ depth, respectively) where chloride also contributes significantly to the calculated conductivity, it is clear that (2) overestimates $\sigma_{\infty}$. In fact, no ice (except doped ice) has been measured before in which both components have been present. Equation (2) may not be appropriate in this case because the $\mathrm{L}$ and $\mathrm{D}$ defects can combine, and their concentrations are the result of an equilibrium. A revised equation should account for this interaction, which will reduce $\sigma_{\infty}$ below that expected from (2). Estimates in which we make a crude attempt to allow for this also give a good fit to the data. However, for this basal ice in general, the assumption that ammonium dominates the conductivity seems correct.

\section{Origin of the Ammonium Signal}

Ammonium $\left(\mathrm{NH}_{4}{ }^{+}\right)$is originally emitted as ammonia $\left(\mathrm{NH}_{3}\right)$, predominantly from continental sources of biogenic origin, mainly bacterial decomposition in soils and biomass burning. Legrand et al. [1992] and Fuhrer et al. [1993] discussed the origin of the $\mathrm{NH}_{4}^{+}$signal in the detailed profiles measured along the GRIP core above the basal silty ice. The background level is generally higher in the present interglacial $(0.4-0.8 \mu \mathrm{M})$ than in the last glacial period (around $0.2 \mu \mathrm{M}$ ). These authors suggest that soil emissions are the principal source for this low-signal record, with a possible slight contribution from the sea ice zone. Ammonium peaks occur in both climatic periods but reach much higher levels in the present interglacial (up to $600 \mathrm{ng} \mathrm{g}^{-1}=33 \mu \mathrm{M}$ ) than during the last glacial (only up to a few $\mu \mathrm{M})$. Legrand et al. compare the strong and narrow peaks they observe between 100 and $600 \mathrm{~m}$ depth in the core (330-2500 years B.P.) to the measurements of organic acids at the same levels (formate $\left(\mathrm{HCOO}^{-}\right)$, acetate $\left(\mathrm{CH}_{3} \mathrm{COO}^{-}\right)$, and oxalate $\left.\left(\mathrm{C}_{2} \mathrm{O}_{4}^{--}\right)\right)$. Formate is dominant, showing clear synchronous peaks with $\mathrm{NH}_{4}{ }^{+}$and relative abundances close to those expected from the $\mathrm{NH}_{4}{ }^{+} / \mathrm{HCOO}^{-}$ molar ratio. $\mathrm{NH}_{4}^{+}$thus primarily occurs as ammonium formate in the peaks, and this is used by Legrand et al. to demonstrate that biomass burning from high-latitude forest fires is the most likely source for the high $\mathrm{NH}_{4}{ }^{+}$levels in the studied sections of the core.

The picture looks, however, quite different in the case of the basal ice from GRIP, as shown in Figure 5. Oxalate is now the dominant organic acid species (about 2 orders of magnitude higher than in all of the other sections measured in the GRIP core) and of all three organic acids measured 

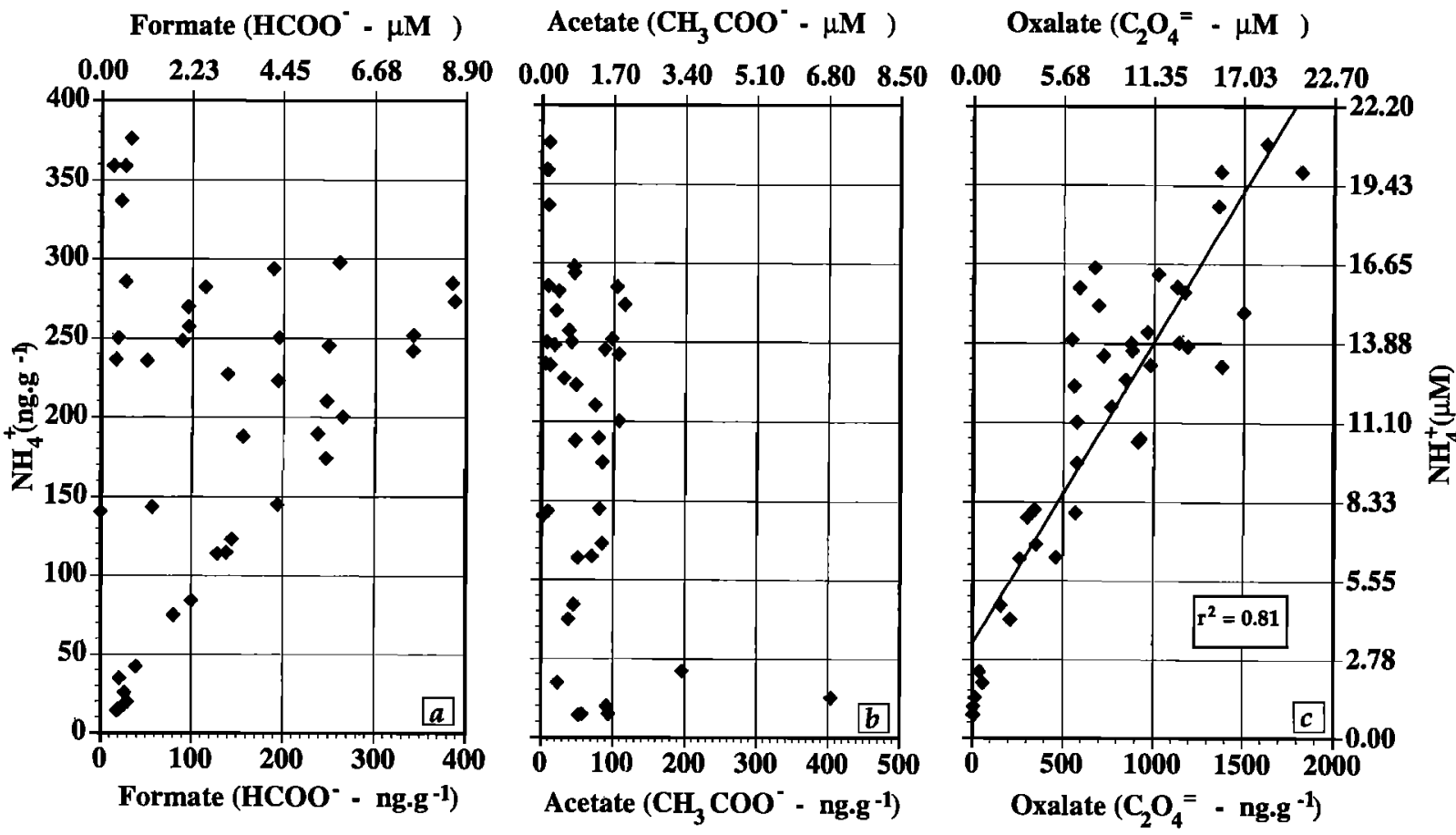

Figure 5. Correlations are shown between ammonium and (a) formate, (b) acetate, and (c) oxalate for the samples in the basal silty ice sequence from GRIP.

in this case, is the one that shows the strongest positive correlation $\left(\mathrm{r}^{2}=0.81\right)$ with ammonium. Oxalate is known to be present in plants (lichens, for example) and also to be one of the by-products of the bacterial degradation of organic matter. In particular, production of ammonium oxalate during uric acid breakdown is a well-described process in the literature (see, for example, Hutchinson [1950] and Legrand et al. [1998]). In this regard, the close association of oxalate and ammonium has been recently demonstrated as being one of the fingerprints of ornithogenic soils (contaminated by animal excreta, in that case, penguin's droppings) in the aerosols and snow deposits of the Terre Adelie area [Legrand et al., 1998]. The data from Figure 5 therefore suggest the existence of considerably deglaciated areas, with significant plant cover and efficient biological activity, in the close vicinity of the formation site of the local end-member involved in the basal ice sequence at GRIP. Conversely, this is a further argument to demonstrate that part of the ice in this basal sequence originated in a periglacial environment in the central part of Greenland, before the settling of the present-day ice sheet. In situ growth of the ice sheet or "invasion" by a growing ice sheet born in the Eastern Greenland mountain range seem equally plausible mechanisms in this context. However, the contrast in chlorine content between the local and the "foreign" end-members (see above), between the stable isotopes and the gas contents of the upper unit of the basal ice [Souchez, 1997], and between the isotopic composition of the embedded debris [Weis et al., 1997] all favor the latter hypothesis.

As underlined in section 4, the behavior of $\sigma_{\infty}$ in Figure $3 \mathrm{f}$ shows that ammonium is tightly associated with the gaseous phase, which suggests that it initially partly occurred as $\mathrm{NH}_{3}$. This implies alkaline conditions in the medium [Stumm and Morgan, 1996]. We have seen from the comparison between calculated and observed DEP that $\left[\mathrm{H}^{+}\right]$must be negligible, and this is further supported by the observation that the ionic balance $([\mathrm{H}-\mathrm{ACY}])$ is negative for all the samples. The full chemical picture of the basal ice layer is, however, far more complex since major cations like $\mathrm{Ca}^{++}$and $\mathrm{Mg}^{++}$also show a good linear relationship to $\mathrm{C}_{2} \mathrm{O}_{4}{ }^{--}$and since some of the ammonium could also exist in the formate form (see Figure 5a), but this is beyond the scope of the present work.

\section{Conclusion}

DEP conductivities of the basal silty ice sequence appear to be essentially controlled by intracrystalline processes due to pure ice and to the effect of additional Bjerrum D defects caused by the inclusion of both $\mathrm{NH}_{3}$ and $\mathrm{NH}_{4}{ }^{+}$into the ice lattice. In the past there has been some discussion [Moore et al., 1994b] of whether the dielectric response of ammonium peaks in shallower parts of the GRIP core was entirely due to ammonium or could also indicate the formation of $\mathrm{L}$ defects from formate. The fact that the points with the highest ammonium content (in Figure 5) are clearly not associated with formate but probably with oxalate, yet they fit on the same calibration curve as the earlier results, strongly suggests that only ammonium (producing D defects) is involved. The electrical behavior of the basal silty ice differs from that observed higher up in the core, where high $\sigma_{\infty}$ (observed during warm climatic episodes) also correspond to high dc conductivities (ECM), indicating a considerable contribution from $\left[\mathrm{H}^{+}\right]$eventually occurring at the boundaries of the crystals. This is understandable since ice formed (or transported) close to the bedrock and loaded with debris inclusions is likely to be 
alkaline. Another unique feature of the basal sequence is the source for the $\mathrm{NH}_{3}$ emissions. Whilst long-distance transport of the products from biomass burning events seems to control the bulk of the peaks in the higher parts of the GRIP core, the dominance of oxalate and its clear correlation with ammonium in the basal sequence support local biogenic production in a periglacial biotope as a likely source. Considering that there is a net excess of oxalate as compared to what would result from uric acid degradation alone, this local biogenic production covers both plants and animals. This is of crucial importance since it obviously implies the absence of the ice- sheet to allow for significant inputs from this low level and lowintensity source. It therefore strongly corroborates the findings deduced from other variables and discussed in previous studies [Souchez et al., 1995a, b, 1994; Tison et al., 1994].

Acknowledgments. This work is a contribution to the Greenland Ice Core Project (GRIP) organized by the European Science Foundation. We thank the GRIP participants and supporters for their cooperative effort. We also thank the National Science Foundations in Belgium, Denmark, France, Germany, Iceland, Italy, Switzerland, and the United Kingdom, as well as the XII Directorate of the E.C. This paper is a contribution to the Belgian Global Change Program (Science Policy Office). J.-L. Tison is Research Associate at the Belgian F.N.R.S.

\section{References}

Alder, B., J. Geiss, N. Groegler, and A. Renaud, Gas composition in ice samples collected by E.G.I.G. in Greenland, Medd. Groenl., 177(2), 101-107, 1969.

Camplin, G.C., J.W. Glen, and J.G. Paren, Theoretical models for interpreting the dielectric behaviour of HF-doped ice, $J$. Glaciol., 21(85), 123-142, 1978.

Caroll, D., Ion exchange in clays and other minerals, Geol. Soc. Am. Bull., 70, 749-780, 1959.

Davidson, D.W., Clathrate hydrates, in Water: $A$ Comprehensive Treatise, vol.2, edited by F. Franks, pp. 115-234, Plenum, New York, 1973.

Fuhrer, K., A. Neftel, M. Anklin, and V. Maggi, Continuous measurements of hydrogen peroxide, formaldehyde, calcium and ammonium concentrations along the new GRIP ice core from Summit, Central Greenland, Atmos. Environ., 27A(12), 1873-1880, 1993.

Gough, S.R., and D.W. Davidson, Dielectric properties of clathrate ices, in Physics and Chemistry of Ice, edited by. E. Whalley, S.J. Jones, and L.W. Gold, pp. 51-55, R. Soc. of Can., Ottawa, Ont., Canada, 1973.

Hammer, C.U., Acidity of polar ice cores in relation to absolute dating, past volcanism and radio echoes, J. Glaciol., 25(93), 359-372, 1980.

Hammer, C.U., Initial direct current in the build-up of space charges and the acidity of ice cores, J. Phys. Chem., 87, 4099-4103, 1983.

Hellferich, F., Ion Exchange, 624 pp., McGraw-Hill, New York, 1962.

Hobbs, P.V., Ice Physics, 837 pp., Clarendon, Oxford, England, 1974.

Hutchinson, G.E., Survey of existing knowledge of biogeochemistry, 3, The biogeochemistry of vertebrate excreta, Bull. Am. Mus. Nat. Hist., 96, 71-94, 1950.

Legrand, M., M. De Angelis, T. Staffelbach, A. Neftel, and B. Stauffer, Large perturbations of ammonium and organic acids content in the Summit-Greenland ice core: Fingerprint from forest fires?, Geophys. Res. Lett., 19(5), 473-475, 1992.

Legrand, M., M. De Angelis, and F. Maupetit, Field investigation of major and minor ions along Summit (Central
Greenland) ice cores by ion chromatography, $J$. Chromatogr., 640, 250-258, 1993.

Legrand, M., F. Ducroz, D. Wagenbach, R. Mulvaney, and J. Hall, Ammonium in coastal antarctic aerosol and snow: Role of polar ocean and penguin emissions, J. Geophys. Res., 103, 11,043-11,056, 1998

Moore, J.C., and J.G. Paren, A new technique for dielectric logging of Antarctic ice cores, J. Phys., Paris, 48(C1), 155-160, 1987.

Moore, J.C., R. Mulvaney, and J.G. Paren, Dielectric stratigraphy of ice: A new technique for determining total ionic concentrations in polar ice cores, Geophys. Res. Lett., 16(10), 1177-1180, 1989.

Moore, J.C., J.G. Paren, and H. Oerter, Sea salt dependent electrical conduction in polar ice, J. Geophys. Res., 97(B13), 19,803-19,812, 1992a.

Moore, J.C., E.W. Wolff, H.B. Clausen, and C.U. Hammer, The chemical basis for the electrical stratigraphy of ice, $J$. Geophys. Res., 97(B2), 1887-1896, 1992b.

Moore, J.C., A.P. Reid, and J. Kipfstuhl, Microstructure and electrical properties of marine ice and its relationship to meteoric ice and sea ice, J. Geophys. Res., 99(C3), 51715180, 1994a.

Moore, J.C., E.W. Wolff, H.B. Clausen, C.U. Hammer, M.R. Legrand, and K. Fuhrer, Electrical response of the SummitGreenland ice core to ammonium, sulphuric acid, and hydrochloric acid, Geophys. Res. Lett., 21(7), 565-568, $1994 b$.

Mulvaney, R., E.W. Wolff, and K. Oates, Sulphuric acid at grain boundaries in Antarctic ice, Nature, 331, 247-249, 1988.

Paren, J.G., and J.W. Glen, Electrical behaviour of finely divided ice, J. Glaciol., 2I(85), 173-191, 1978.

Petrenko, V.F., Electrical Properties of ice, Spec. Rep. 93-20, 69 pp., Cold Reg. Res. and Eng. Lab., Hanover, N.H., 1993.

Souchez, R., The build up of the ice sheet in Central Greenland, J. Geophys. Res., 102(C12), 26,317-26,323, 1997.

Souchez, R., J.-L. Tison, R. Lorrain, L. Janssens, M. Stievenard, J. Jouzel, A. Sveinbjörnsdottir, and S.J. Johnsen, Stable isotopes in the basal silty ice preserved in the Greenland Ice Sheet at Summit: Environmental implications, Geophys. Res. Lett., 21(8), 693-696, 1994.

Souchez, R., L. Janssens, M. Lemmens, and B. Stauffer, Very low oxygen concentration in basal ice from Summit, Central Greenland, Geophys. Res. Lett., 22(15), 20012004, 1995a.

Souchez, R., M. Lemmens, and J. Chappellaz, Flow-induced mixing in the GRIP basal ice deduced from the $\mathrm{CO}_{2}$ and $\mathrm{CH}_{4}$ records, Geophys. Res. Lett., 22(1), 41-44, 1995 b.

Stumm, W, and J.J. Morgan, Aquatic Chemistry: Chemical Equilibria and Rates in Natural Waters, 3rd ed., 1022 pp., Wiley-Interscience, New York, 1996.

Tison, J.-L., Diamond -wire saw cutting technique for investigating textures and fabrics of debris-laden ice and brittle ice, J. Glaciol., 40(135), 410-414, 1994.

Tison, J.-L., T. Thorsteinsson, R. Lorrain, and J. Kipfstuhl, Origin and development of textures and fabrics in basal ice at Summit, Central Greenland, Earth Planet. Sci. Lett., 125(1-4), 421-437, 1994.

Weis, D., D. Demaiffe, R. Souchez, A.J. Gow, and D.A. Meese, Ice sheet development in Central Greenland: Implications from the $\mathrm{Nd}, \mathrm{Sr}$ and $\mathrm{Pb}$ isotopic compositions of basal material, Earth Planet. Sci. Lett., 150, 161-169, 1997.

Wolff, E.W., J.C. Moore, H.B. Clausen, C.U. Hammer, J. Kipfstuhl, and $\mathbf{K}$. Fuhrer, Long-term changes in the acid and salt concentrations of the Greenland Ice Core Project ice core from electrical stratigraphy, J. Geophys. Res., 100(D8), 16,249-16,263, 1995.

Wolff, E.W., W.D. Miners, J.C. Moore, and J. Paren, Factors controlling the electrical conductivity of ice from the polar regions: A summary, J. Phys. Chem., B101, 6090-6094, 1997a. 
Wolff, E.W., J.C. Moore, H.B. Clausen, and C.U. Hammer, Climatic implications of background acidity and other chemistry derived from electrical studies of the Greenland Ice Core Project ice core, J. Geophys. Res., 102(C12), 26,325-26,332, $1997 \mathrm{~b}$.

M. de Angelis and M.R. Legrand, Laboratoire de Glaciologie et Géophysique de l'Environnement, CNRS, Grenoble, France. (e-mail: mimi@glaciog.grenet.fr)

J.C. Moore, Arctic Center, University of Lapland, Rovianemi, Finland. (e-mail: jmoore@roisrv.urova.fi)
R. Souchez and J.-L. Tison, Université Libre de Bruxelles, Département des Sciences de la Terre et de l'Environnement, CP 160-03, Avenue F.D. Roosevelt 50, Bruxelles B-1050, Belgium. (e-mail: glaciol@ulb.ac.be)

E.W. Wolff, British Antarctic Survey, National Environment Research Council, Cambridge, England, U.K. (e-mail: ewwo@pcmail.nerc-bas.ac.uk)

(Received November 13, 1997; revised March 26, 1998; accepted March 31, 1998.) 